\title{
Tourist spaces and tourism policy in Spain and Portugal
}

\author{
Fernando Almeida \\ Faculty of Tourism \\ University of Málaga, Spain \\ E-mail: falmeida@uma.es \\ $\&$ \\ Rafael Cortés \\ Faculty of Tourism \\ University of Málaga, Spain \\ E-mail:rcortes@uma.es \\ $\&$ \\ Antonia Balbuena \\ Faculty of Tourism \\ University of Málaga, Spain \\ E-mail: abalvaz@yahoo.es
}

\section{Introduction}

The territorial and geographical factor plays a key role in the development of tourist destinations. The territory and its resources are those that provide identity to the destinations. But tourism resources are not distributed equitably, so that tourism tends to create territorial imbalances. This is explained by the close relationship between tourism and territorial resources (beaches, landscape, heritage, etc.) and the duty to use these resources in the own tourism destination.

This study analyses the relationships between tourism, tourism resources and regional imbalances in Spain and Portugal. There are few comparative studies between tourism policy and territorial processes in Spain and Portugal. This is one of the contributions of this study.

Research into tourism policy has generally focused on specific countries, analyzing the subject as a branch of national policy and approaching the task in large, regional blocks (Lickorish, 1991). To date, there has been relatively little analysis contrasting the tourism policies of different countries, though several interesting studies have been carried out in Europe (Swarbrooke, 1993). Spain and Portugal, however, have rarely been compared, despite their geographical proximity and the existence of socioeconomic processes that are common to both. Most of the references to these countries currently available are to be found either in studies dealing with tourism in Europe in general, Southern Europe or the Mediterranean area (Akehurst, Bland \& Kevin, 1993; Apostolopoulos, et al., 2001), or in series of publications compiled by international organizations such as the OECD and the WTO. Worthy of special mention are the analyses of tourism policy in Spain and Portugal undertaken by Williams $(1988,1993)$, which assess the role played by tourism in both national 
economic development and regional imbalance, although none of these deals specifically with the two countries alone. Our study of Spain and Portugal adopts a similar approach to the one taken by Williams, though with the inclusion of other facets such as the process via which national tourism policy is constructed.

An examination of Spain and Portugal's shared history reveals parallel development as far as tourism policies and models are concerned, although the tourism processes in the two countries also display certain differences due to their differing socioeconomic development. The evolution of tourism policy can be divided into the three main stages identified by Fayos-Solá (1996):

The Fordian phase: the first stage, between 1950 and 1975, brought a series of important developments. The lberian nations now understood that tourism held the key to economic growth. Indeed, several authors maintain that this period saw the introduction of a uniquely Latin model of development which was heavily reliant on tourism (Bote, 1998). Franco's dictatorship used tourism to improve Spain's foreign image (Correyero \& Cal, 2008), as, to a lesser degree, did Salazar's own in Portugal (Almuiña, 2002). This phase also marked the first major divergence between the two countries in terms of tourism policy: whereas the Spanish government committed itself fully to mass tourism as a means of maximizing revenue and investment (Cals, 1974), the Portuguese opted instead to maintain a more gradual rate of tourist growth (Cunha, 2009). In fact, mass tourism was the dominant theme during this period, and tourism-based development is the facet of tourism most frequently studied by both Spanish and Portuguese authors.

The post-Fordian phase: during the third stage of our study, Spanish and Portuguese society began to act in unison. The dictatorships in both countries ended in successive years (1974/75), they joined the European Union (1986), adopted the Euro (2001), and experienced similar economic ups and downs. However, their respective administrative structures and tourism planning procedures took vastly different paths. While Spain's heavily-centralized policy was replaced by a decentralized system overseen by its Autonomous Communities and the tourist towns themselves, in Portugal, the exact opposite now occurred. This chapter examines the effectiveness of tourism policies in terms of generating revenue and adapting to the changes in the sector introduced by the post-Fordian model of management based on competitiveness, quality and sustainability (Fayos-Solá (1996). Regional policy, the restructuring of the tourism sector, and the social and environmental impact of tourism are the aspects most commonly identified by authors as the main consequences of the protracted growth of tourism in Spain and Portugal.

This study provides a comparative analysis of tourism policy in Spain and Portugal and the spatial effects. This paper aims to compare the evolution of tourism policies of the two countries since 1960. Also, it analyses the territorial imbalances caused by tourism in Spain and Portugal.

It aims to demonstrate that territorial unbalances caused by tourism were part of the unbalanced model that was introduced in Spain and Portugal. This socioeconomic model has been maintained over time. 


\section{Methods and Materials}

To carry out this study we have made a comprehensive literature review of major studies on tourism policy of Spain and Portugal. We have collected the main sources of tourism statistics. The statistical data are required to understand the evolution of tourism and to compare tourism issue of both countries. The main variable used by this study is the supply of hotel accommodation, secondly foreign tourists and foreign visitors. The main tourist factors are indicated by figures and tables. This variable was chosen because it has a close relationship with the territorial changes and it also represents tourism offer. Furthermore, the hotel supply with tourism demand, are the most suitable variables to show the evolution of tourism policy.

The analysis period is between 1960 and 2010. At the end, we carry out an analysis that shows maps representing changes in tourism policy of Spain and Portugal. A database of the hotels has been made with a spatial reference in each of the countries (Districts and NUT III in Portugal and Province in Spain). This database was exported and referenced to the GIS base map.

\section{Research and Results}

The tourism trend to cause regional imbalance was not prevented by pre-democratic governments of Spain and Portugal. In the 1960s the supply of hotel accommodation was highly concentrated in the regions of Lisbon (Portugal) and Spanish Mediterranean provinces (Gerona, Barcelona, Baleares and Malaga) (Map 1968). This scenario was changed in the following decades. In the 1980s and 1990s it had been a spread of tourism accommodation supply to former no tourist areas. This process was due to the need to diversify tourism sector, the lack of competitiveness in some saturated coastal areas and the interest of local and regional governments to development the inland regions and real estate sector needs that demanded new areas for the building of second homes.

Table 1

Hotel places by region and major tourist destination (\%)

\begin{tabular}{lrrrrr}
\hline \% of Total Hotel Places & 1963 & 1973 & 1983 & 1993 & 2007 \\
\hline Lisbon Region & 41.9 & 39.4 & 32.3 & 24.5 & 22.4 \\
Algarve & 5.0 & 19.1 & 33.8 & 39.9 & 24.4 \\
Madeira Islands & 3.3 & 14.2 & 10.3 & 8.5 & 12.2 \\
Rest of Portugal & 49.8 & 27.3 & 23.6 & 27.1 & 41.0 \\
Alicante & 3.8 & 5.9 & 5.9 & 4.9 & 4.9 \\
Balearic Islands & 17.8 & 30.9 & 27.2 & 25.6 & 14.3 \\
Barcelona $_{\text {Canary Islands }}$ & 13.4 & 8.6 & 7.5 & 7.5 & 6.7 \\
Gerona $_{\text {Madrid }}$ & 5.4 & 6.8 & 8.4 & 8.4 & 14.9 \\
Malaga & 17.4 & 10.2 & 8.8 & 7.5 & 4.1 \\
Rest of Spain $_{\text {Spanish Mediterranean }}{ }^{\text {a }}$ & 12.6 & 6.3 & 5.8 & 5.1 & 6.8 \\
& 4.9 & 4.8 & 5.7 & 5.3 & 6.0 \\
\hline
\end{tabular}

Source: INE (National Institute of Statistics, Spain and Portugal), Ministry of Information and Tourism of Spain (1951-77).

a Provinces of Alicante, Barcelona, Gerona, Malaga and Valencia, and the Balearic Islands. 
We can confirm there has been a very strong concentration of the hotels on the Spanish Mediterranean coastline, Balearic Islands, Canary Islands and Madeira in 2009. Almost the whole coastline of the Iberian Peninsula has become a tourist belt, this excludes small coastal stretches (coastal Alentejo in Portugal and the Spanish province of Lugo in northern Spain). The islands have a strong tourist density (Map 2009).

The following are the main conclusions of the communication.

Before the great development of mass tourism in Portugal and Spain, tourist accommodation supply was quite low and was relatively equality distributed across the country. The varying range of accommodation depends on the size of the demographic area.

At the time of the great tourism growth in the middle 1960s (mostly in Spain), the supply of tourist accommodation is concentrated on the Mediterranean coast (Baleares, Gerona, Barcelona, Alicante and Malaga). The huge growth of the Algarve was later.

In the 1980s there was a strong focus on the Spanish Mediterranean coast in both Spanish and the archipelagos (Balearic and Canary Islands). In Portugal, the areas with the highest tourism concentration were Lisbon, Algarve and Madeira.

From the 1990, a spare of tourism to inland areas of Spain and Portugal was produced and this process was extended to the last undisturbed coastal areas of the Atlantic and the Mediterranean.

The distribution of tourism in the two countries was unbalanced and helped more regions economic development. Tourist sector was encouraged to finance the national development of the industrial sectors.

Figure 1

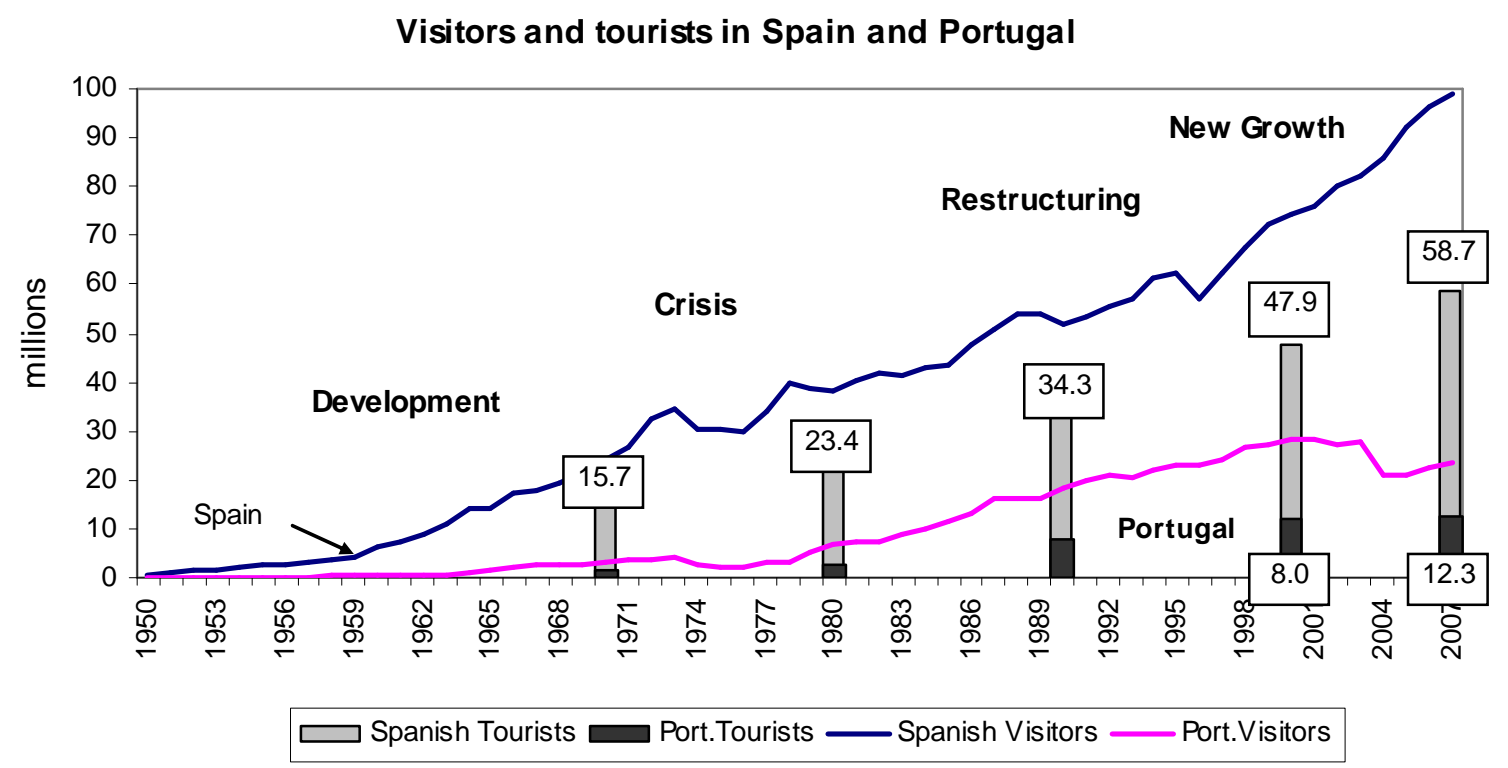

Source: INE (National Institute of Stastistics) Spain and Portugal. Note: Methodological change en 2004 (Portugal) 


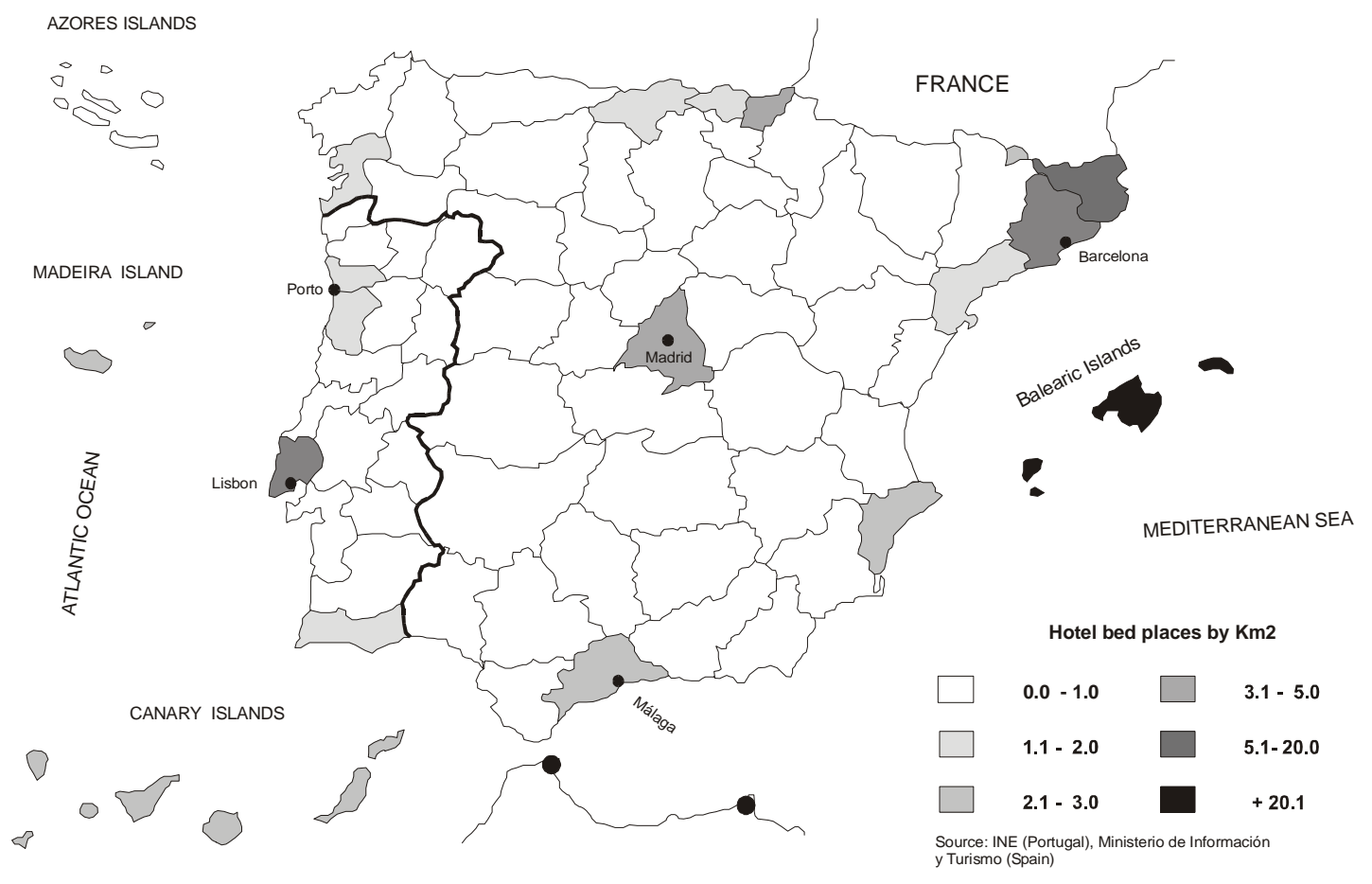

DENSITY OF HOTEL PLACES. PROVINCES (SPAIN) AND NUTS III (PORTUGAL). 2009.

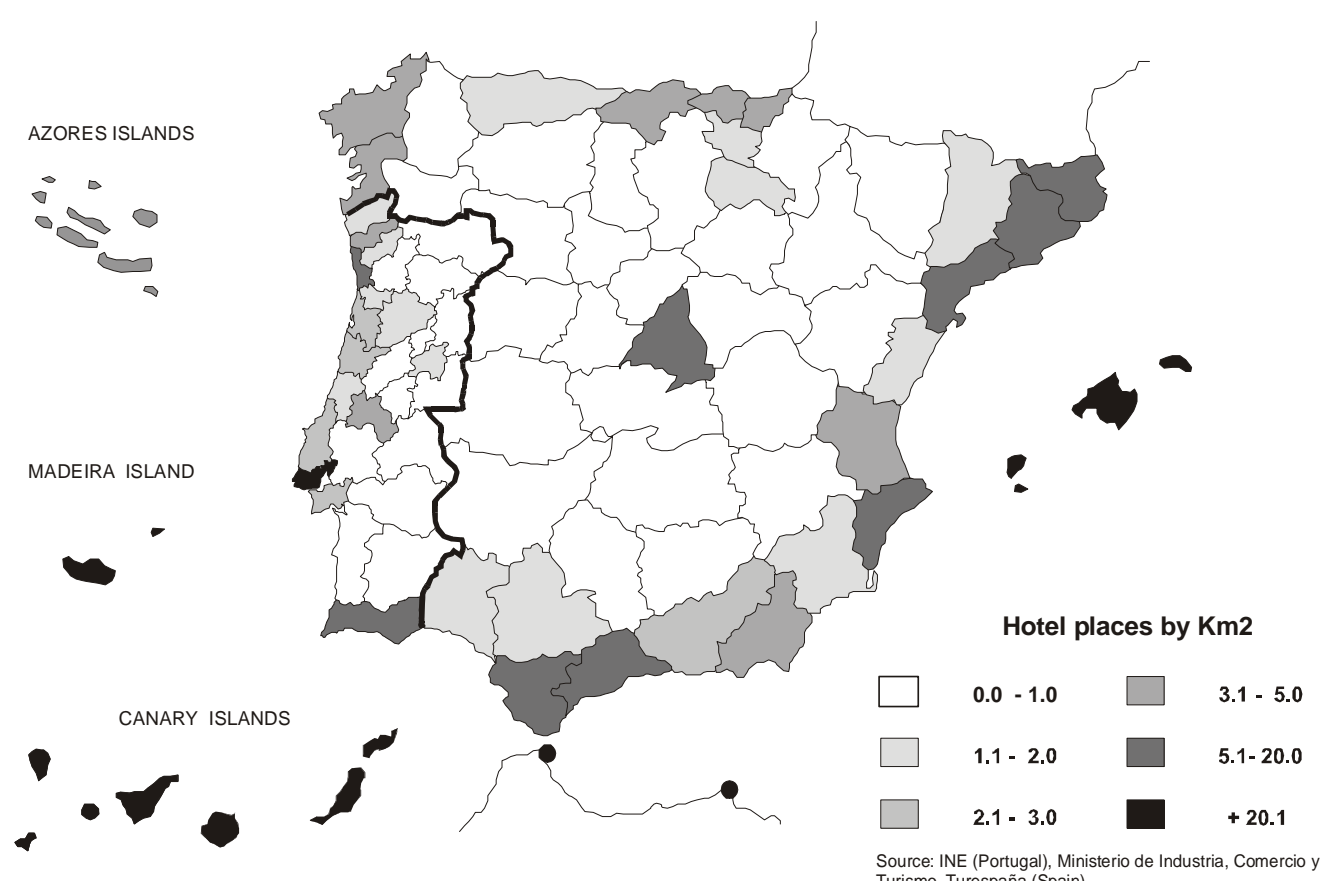

Source: INE (Portugal), Ministerio de Industria, Comercio y urismo, Turespaña (Spain) 


\section{Conclusion and Implications}

Spain's sun and sand tourism sector has continued to grow, generating sufficient economy of scale to keep its production costs low. The internationalization of the country's hotel chains, notably in the Balearic Islands, represents an exportation of this continuous process of growth and the search for low costs. However, the Spanish tourism sector has also diversified, with cultural and culinary tourism among the alternatives now joining sun and sand vacations. Portugal, meanwhile, has turned its back on luxury tourism and is now belatedly exploiting the sun and sand market instead, though strenuous efforts have also been made to develop cultural and nature tourism. The Portuguese tourism sector has yet to reach full maturity.

Certain authors highlight the existence of a Latin model of development based on tourism. While the characteristics of this approach are not radically different from those of subsequent methodologies implemented in tourist-receiving countries, its significance lies in the fact that it was the first of the mass tourism era, a period which would ultimately transform the nations concerned into developed countries. In the Latin model, the role of the tourism sector was to provide resources (tourist revenue) that could be invested in industry. Spain's case is unique in that the early days of tourism saw the country open up to and rely upon foreign countries in much the same way as the small tourist nations of the Caribbean, the Indian Ocean and Oceania would do years later. In spite of this, the situation in Spain evolved towards greater independence, with Spanish hotel chains even replicating this model of Dependence in the Caribbean.

\section{Acknowledgement}

This research project has received funding from the Spanish Government, Fundamental Research Program (CSO2012-30840), “Geographies of crisis: analysis of urban territories of the Balearic Islands tourism Costa del Sol and main tourist destinations of the Caribbean".

\section{References}

Akehurst, G., Bland, N., \& Kevin, M. (1993). Tourism policies in the European Community member states. Journal of Hospitality Management, 12(1), 33-66. doi:10.1016/0278-4319(93)90040-G

Almuiña Fernandes, C. (2002). Análisis comparativo entre los modelos propagandísticos Salazarista y franquista. In C. Almuiña, F. De Sousa \& M. Meireles (Eds.), Relações Portugal-Espanha. Uma história paralela, um destino comum? Porto: CEPESE \& Fundação Rei Afonso Henriques.

Apostolopoulos, Y., Loukissas, P., \& Leontidou, L. (Eds.) (2001). Mediterranean Tourism. Facets of socioeconomic development and cultural change, London: Routledge. 
Bote Gómez, V. (1998). El desarrollo del turismo en España: cambio de rumbo y oportunidades científicas. Revista Valenciana D`Estudis Autonómics, 4, 29-43.

Cals Güel, J. (1974). Turismo y política turística en España: una aproximación. Barcelona: Ariel.

Correyero, B. \& Cal, R. (2008). Turismo: la mayor propaganda de Estado. España: desde sus inicios hasta 1951, Madrid: Visión Net.

Cunha L. (2003). Perspectivas e tendências do turismo. Lisboa: Edições Universitárias Lusófonas.

Fayos-Solá, E. (1996). La nueva política turística. In R. Barba \& R Pié (Eds.), Arquitectura y turismo: planes y proyectos (pp.59-70). Barcelona: Universitar Politècnica de Cataluyna.

Lickorish, L.J. (1911). Developing a single European tourism policy. Tourism Management, September, 179-184.

Swarbrooke, J (1993). Public sector policy in tourism: a comparative study of France and Britain, Insights, March, C33-C46.

Williams, A.M. \& Shaw, G. (Eds.), (1988). Tourism and Economic Development. Western European experiences. London: Pinter Publishers.

Williams, A.M. (1993). Tourism and economic transformation in Greece and Portugal, Inforgeo, 6, 7-20. 